\title{
Racism and Antiracism in the Liberal International Order
}

\author{
Zoltán I. Búzás ๑
}

\begin{abstract}
Formal racial equality is a key aspect of the current Liberal International Order (LIO). It is subject to two main challenges: resurgent racial nationalism and substantive racial inequality. Combining work in International Relations with interdisciplinary studies on race, I submit that these challenges are the latest iteration of struggles between two transnational coalitions over the LIO's central racial provisions, which I call racial diversity regimes (RDRs). The traditional coalition has historically favored RDRs based on racial inequality and racial nationalism. The transformative coalition has favored RDRs based on racial equality and nonracial nationalism. I illustrate the argument by tracing the development of the liberal order's RDR as a function of intercoalitional struggles from one based on racial nationalism and inequality in 1919 to the current regime based on nonracial nationalism and limited equality. Today, racial nationalists belong to the traditional coalition and critics of racial inequality are part of the transformative coalition. The stakes of their struggles are high because they will determine whether we will live in a more racist or a more antiracist world. This article articulates a comprehensive framework that places race at the heart of the liberal order, offers the novel concept of "embedded racism" to capture how sovereignty shields domestic racism from foreign interference, and proposes an agenda for mainstream International Relations that takes race seriously.
\end{abstract}

Racial equality has an ambivalent relationship with the Liberal International Order (LIO). At the 1945 San Francisco Conference, many participants attributed World War II to racism, and deemed the inclusion of racial equality in the United Nations Charter vital for peace in the new international order. Subsequent efforts have strengthened racial equality. The United Nations General Assembly (UNGA) has issued more than 220 resolutions related to racial equality, perhaps its most popular topic. ${ }^{1}$ The first legally binding human rights treaty to come into force was the International Convention on the Elimination of All Forms of Racial Discrimination (1969). The LIO's formal racial equality is now enshrined in many international laws, norms, institutions, and practices.

Despite this progress, the LIO's racial equality dimension remains fundamentally limited. Racial equality is often interpreted narrowly as equality of treatment rather than broadly as equality of outcomes, curbing its ability to challenge systemic

1. This count includes resolutions on racial equality, racism, discrimination, xenophobia, apartheid, and indigenous issues; for the argument that racial equality may be the most popular UNGA resolution topic see Lauren 1996, 4. 
racism. The enforcement of racial equality laws is still insufficient. States have resisted key racial equality provisions through means such as the doctrine of domestic jurisdiction. Substantive racial inequality remains widespread despite the proliferation of formal racial equality.

This ambivalent relationship between racial equality and the LIO has always been subject to some discontent, but today it faces two renewed challenges. The first, less justified challenge is the resurgence of racial nationalism, which sees the order's racial equality as too strong and aims to weaken it. Racial nationalism determines membership in the nation based on allegedly natural attributes such as shared bloodlines. ${ }^{2}$ It hardens differences between "true" members of the nation and others, legitimates discrimination against foreigners and citizens of the "wrong" race or ethnicity, and misrepresents efforts to advance racial equality as "reverse discrimination." Although its different strands thrive in many places, including China and India, its white nationalist version poses arguably the most visible challenge to the LIO. White nationalists regard immigration and the rise of China partly as racial threats that undermine the demographic, cultural, economic, and geopolitical dimensions of white dominance and even survival. ${ }^{3}$ They and their allies blame these threats on the LIO and cosmopolitan elites' support for racial equality, broad-minded immigration and citizenship laws, multiculturalism, and affirmative action. From this perspective, the LIO's racial equality has gone too far.

The second, more justified challenge to the LIO's formal racial equality is the persistence of substantive racial inequality and discrimination. Critics of racial inequality see the order's racial equality as insufficiently strong, and aim to fortify it. This longstanding challenge has acquired renewed urgency at the time of writing because of the global diffusion of Black Lives Matter protests, the rise of emerging powers, and the vast racial inequalities exposed and amplified by COVID-19. ${ }^{4}$ African leaders accuse the International Criminal Court of anti-African bias, with Gambian Information Minister Sheriff Bojan labeling it the International Caucasian Court. ${ }^{5}$ NonWestern states lament their under-representation in key LIO institutions such as the United Nations Security Council (UNSC). ${ }^{6}$ There are worries that the LIO and liberal states perpetuate racial inequality by restricting immigration from poor black to rich white states, upholding economic rules favorable to the latter, and hindering redistributive justice. ${ }^{7}$ Seventy-five years after the San Francisco Conference, from this perspective, the LIO's formal racial equality has still not gone far enough. It

2. Gerstle 2001 .

3. Mutz 2018; Adam Taylor, “The Worst Justification for Trump's Battle with China? The 'Clash of Civilizations,", Washington Post, 2 May 2019.

4. Damien Cave, Livia Albeck-Ripka, and Iliana Magra, "Huge Crowds Around the Globe March in Solidarity Against Police Brutality," New York Times, 6 June 2020; "The Grim Racial Inequalities Behind America's Protests," The Economist, 3 June 2020.

5. DeFalco and Mégret 2019, 56.

6. For a recent example, see United Nations 2018.

7. Anievas, Manchanda, and Shilliam 2015; on racial inequality intertwined with class and gender see also Gruffydd Jones 2008; Klotz 2017; and Parmar 2018; on normative perspectives see Bell 2019. 
is at best ineffective at countering substantive racial inequality, and at worst is complicit in producing and legitimating inequality. In the words of a sign at the global antiracist protests unleashed by George Floyd's killing by the Minneapolis police on 25 May 2020: "We didn't come this far to only come this far."

How can we make sense of these colliding racial challenges and what are their implications for the LIO? Combining work in International Relations (IR) with interdisciplinary studies on race, I submit that these challenges are the latest iteration of struggles between two transnational coalitions over the LIO's central racial provisions. My starting point is that these racial provisions shape the LIO's legitimacy, and that they constitute what I call "racial diversity regimes" (RDRs). ${ }^{8}$ Adapting Reus-Smit's work, I define RDRs as international institutions, laws, norms, and practices that identify the dominant cultural units that polities should represent (racial or nonracial nations), and relate these cultural units and their individual members to each other (racial equality or inequality). ${ }^{9}$

RDRs are the products of political contests between a traditional coalition that has historically favored racial inequality and racial nations (nations based on ostensibly shared bloodlines), and a transformative coalition that has favored racial equality and nonracial nations (nations based on shared political creeds). ${ }^{10}$ The less RDRs reflect the views of the stronger coalition or of cross-coalitional majorities, the more likely they are to be contested and revised. Depending on whether their revision better reflects traditional or transformative views, resulting RDRs and the associated liberal orders will tend to hurt or help racial equality.

I illustrate the argument by tracing the emergence and development of the liberal order's RDRs from 1919 to the present as a consequence of struggles between the two coalitions. I start with placing the first liberal international order (LIO 1.0) in historical context. I then show that in 1919 the dominant traditional coalition of "AngloSaxon" states and their allies built a regime that favored racial nations and racial inequality (white nations and white supremacy), successfully resisting challenges from a weaker transformative coalition led by Japan. The racist atrocities of World War II and anticolonial nationalists undermined the legitimacy of the discriminatory diversity regime of LIO 1.0. In 1945, the strengthened transformative coalition replaced it with a second liberal order (LIO 2.0) and a new RDR favoring racial equality and nonracial nations. But the traditional coalition limited the egalitarian RDR's scope by what I label "embedded racism," under which sovereignty protected domestic racism from international interference. Transformative efforts consolidated the egalitarian diversity regime through decolonization and the civil rights movement, bringing about LIO 2.5. Still, traditionalist resistance kept formal racial equality limited, preserving room for white nationalism and substantive racial inequality.

8. The label is inspired by "diversity regimes" (Reus-Smit 2017), "regimes of ethnicity" (Aktürk 2011), and "racial regimes" (Hanchard 2018).

9. Reus-Smit 2017.

10. For a similar argument see King and Smith 2011. 
Current racial challenges continue this struggle. White nationalists and their traditionalist allies consider the current diversity regime too strong because it threatens white dominance, which they misrepresent as equality. They threaten to reverse the racial progress, however imperfect, made since 1945. The transformative coalition rightly sees the current RDR as not strong enough, allowing the persistence of racial inequality. It aims to strengthen the RDR. The stakes of the struggles between these two coalitions are high because they will determine the fate of the order's racial equality, and consequently whether we will live in a more racist or a more antiracist world. Transformative forces must mobilize to defend and advance the RDR's commitment to antiracism.

This article's main contribution is a comprehensive framework that places race, which is often overlooked in mainstream IR, at the heart of the LIO. It brings together numerous issues related to racism and antiracism that tend to be studied separately, and traces their joint impact on the LIO. This article also proposes the novel concept of embedded racism to capture how sovereignty shields domestic racism from foreign interference, and articulates an agenda for mainstream IR that takes race seriously.

Having outlined the argument, it is important to stress what I do not argue. First, my focus on white nationalism and white supremacy does not imply the absence of their non-Western equivalents. I touch on these when relevant, but I emphasize white nationalism and white supremacy because these have been the battleground issues between the racial coalitions. Second, this is not a "clash of civilizations" story. ${ }^{11}$ One may worry that because I focus on Western racism, my racial coalitions resemble Huntington's "the West versus the rest." Key differences should allay these worries. Transnational racial coalitions differ from Huntingtonian civilizations, as their members cut across "civilizational" boundaries. Additionally, whereas Huntington treats civilizations as relatively fixed, I treat race as a mutable social construct. Third, this article has benefited greatly from but cannot do justice to the vast scholarship related to race in IR and beyond, such as critical race theory, black radical thought, black feminism, indigenous scholarship, Third World Approaches to International Law, post-development theory, and decolonial and tricontinental thought. ${ }^{12}$ Those interested in learning more about race should consult this thriving work.

In what follows, I sketch the argument that RDRs are the product of racial coalitional struggles. Next, I illustrate the argument in a stylized history of racial struggles over RDRs from 1919 to the present, and consider plausible outcomes to its current challenges. The concluding section highlights the article's contributions, links the

11. Huntington 1996.

12. I thank Robbie Shilliam for this point. Examples of insightful studies include Anderson 2014; Anghie 2004; Anievas, Manchanda, and Shilliam 2015; Bell 2019; Blain 2018; Crawford 2017; Crenshaw et al. 1995; Getachew 2019; Grovogui 1996; Gruffydd Jones 2008; Hanchard 2018; Henderson 2017; Sabaratnam 2017; Sajed and Persaud 2018; Vitalis 2015; and Vucetic 2011. I also discuss some of this valuable work in Búzás 2020. 
argument to the analytic lessons of this issue's framework article, and proposes a racial agenda for mainstream IR.

\section{Racial Diversity Regimes, Racial Coalitions, and the LIO}

According to this issue's framework article, the Liberal International Order is an order because it structures relations among units, it is international because its main members are sovereign states, and it is liberal because it embodies strands of political liberalism, economic liberalism, and liberal internationalism. ${ }^{13}$ The LIO's stability depends not only on the material power of its champions but also on legitimacy, understood as the belief that the order's institutions, laws, and norms should be obeyed. The LIO's legitimacy depends to an important extent on what Reus-Smit calls "diversity regimes." 14

\section{Types of RDRs and the Problem of Embedded Racism}

In my adapted usage, RDRs are international institutions, laws, norms, and practices that identify the dominant cultural units that polities should represent, and relate these cultural units and their individual members to each other. RDRs cut across levels of analysis, but my primary focus is on their international (global and regional) dimensions. For most of the LIO's lifespan, the main polity has been the state, and the dominant cultural unit represented by it has been the nation. This evinces the success of nationalism, a political ideology that promotes convergence between states and nations. There are many types of nationalisms and nations, but all can be categorized as racial or nonracial. For simplicity's sake, I treat them as dichotomous, but they are better seen as ideal-typical end points of a continuum on which nations and nationalisms can be more or less racialized. "Racialization" refers to the construction of relationships, practices, or groups as "racial." 15 In the context of social groups, the key element of being constructed as racial is the hardening of group boundaries, making them appear natural and fixed rather than social and changeable. The concept of "racialization" usefully directs attention to processes through which groups are constructed as racial, highlighting that race is a mutable social fact rather than a fixed biological one.

Racial nationalism defines the nation in terms of ostensibly natural and essential characteristics. It often emphasizes members' shared bloodlines, the markers of which tend to be phenotypic, but can also be essentialized cultural markers that harden intergroup differences, make them appear natural, and legitimate discrimination 
against those seen as fundamentally different. ${ }^{16}$ These markers conceal that shared bloodlines are largely imagined, and that the location of national group boundaries and the traits associated with them are social choices. The more prevalent racial nationalism is, the more impermeable and exclusionary national boundaries tend to be. Those who do not fit its restrictive membership criteria cannot become full members of the nation.

In contrast, nonracial nationalism imagines the nation based on shared political creeds, making the nation's boundaries more permeable. In principle, anyone who accepts these creeds can become a full member. Racial identities can exist in nonracial nations, but they are immaterial for national membership. Although nations typically contain both racial and nonracial elements, at any given time and place they tend to be closer to one or the other end of the spectrum.

RDRs relate nations and their individual members to each other through equality or inequality. To capture the relevant types of difference, I focus on racial equality and contrast it with racial inequality, hierarchy, and discrimination. ${ }^{17}$ At the most general level, the principle of equality entails that like units are entitled to equal treatment, opportunities, and outcomes, whereas the principle of inequality denies this. Narrower meanings of equality and inequality stress treatment (e.g., equal treatment as equality before the law) whereas broader meanings stress opportunities and even outcomes (e.g., equal outcomes as racial quotas). ${ }^{18}$

Variation in dominant cultural units (racial or nonracial nations) and ordering principles (equality or inequality) produces four main configurations of RDRs. These RDRs are based on nonracial nations and racial equality, nonracial nations and racial inequality, racial nations and racial equality, and racial nations and racial inequality. This article's stylized history focuses primarily on the first and last of these. More nuanced variation is also possible within RDRs, such as broader or narrower notions of racial equality.

International RDRs and domestic racial conditions shape each other and over time tend to converge. For example, egalitarian domestic racial conditions in some countries can inspire the design of egalitarian international RDRs, which then can be employed to further advance domestic racial equality. Nonetheless, gaps between RDRs and domestic racial conditions can persist. One reason for such gaps between egalitarian RDRs and domestic racism is what I label embedded racism. Space constraints preclude the thorough articulation of this concept, but the following will point readers in the right direction.

If Ruggie's "embedded liberalism" entails opt-outs that allow domestic deviation from international free-market liberalism, embedded racism involves similar deviation from international racial equality provisions to accommodate domestic 
racism. ${ }^{19}$ Although it aspires to universality in scope, the LIO's egalitarian diversity regime has nonetheless been limited through domestic jurisdiction, reservations, and other similar instruments. An example is Article 2(7) of the United Nations Charter, quoted later, which curtails the United Nations' ability to intervene in states' domestic affairs. As will be shown, this apparently race-neutral article safeguarding states' domestic jurisdiction was designed in part to protect domestic racism from foreign challenges, and was subsequently employed for this purpose. Of course, embedded racism and domestic jurisdiction can be contested. Their ability to protect domestic racism varies and is not fail-safe, as the fall of South African apartheid suggests. Nonetheless, they have done much to allow domestic racism to persist in the egalitarian RDR. Embedded racism intersects with Goodman and Pepinsky's argument that embedded liberalism rests on exclusionary domestic foundations, but it extends that argument from immigrants to citizens with minority backgrounds. ${ }^{20}$

\section{RDRs and Racial Coalitions}

RDRs are the result of political struggles between opposing racial coalitions. ${ }^{21}$ Following King and Smith, I define racial coalitions as loose political networks of actors that take similar positions on the central racial questions of their era. ${ }^{22}$ Who can be part of racial coalitions? Whereas King and Smith's membership criteria are tied to actors who control domestic "governing institutions," this is less suitable for my purposes, because the international equivalent of "governing institutions" is less clear. Instead, I limit membership to actors that are politically active in a broad sense on the relevant international racial issues. These may include public officials, social movements, corporations, public intellectuals, courts, the media, and churches. Members have varying levels of commitment to their coalition, diverse motivations, and multiple goals, not all of which relate to race. Nonetheless, they tend to be on the same side regarding the main racial questions of the day.

As with RDRs, variation in actors' preferred cultural units (racial or nonracial nations) and ordering principles (racial equality or inequality) could yield four main racial coalitions. However, for the sake of tractability and in line with my emphasis on two RDRs, I distinguish between two broad coalitions. One is what I call the transformative coalition, which has been more supportive of racial equality and nonracial nationalism. The other is a traditional coalition that has been more supportive of racial inequality and racial nationalism. Coalition membership can be

19. Ruggie 1992.

20. Goodman and Pepinsky 2021.

21. These struggles overlap with struggles for recognition discussed in Adler-Nissen and Zarakol 2020, but that article's focus is not specifically racial.

22. King and Smith 2011, 18-20. 
identified based on actors' public positions on the main racial questions of the relevant period. ${ }^{23}$

The more RDRs align with the prevailing conceptions of nations and equality of the dominant coalitions or of cross-coalitional majorities, the more stable they will be, and the more they can legitimate the broader LIO. Changes in regimes, power, and actors' views on nations and equality can lead to mismatches between the existing RDR and the views of dominant coalitions or cross-coalitional majorities. When the gap is sufficiently large, regimes come under sustained contestation. They are likely to be revised, through redesign or reinterpretation, to narrow or close this gap. RDRs can be radically revised, for example, by replacing laws, norms, institutions, and practices favoring racial nations and racial inequality (hierarchy) with those favoring nonracial nations and racial equality. RDRs can be revised less radically, for example, by moving from narrower to broader understandings of racial equality. To illustrate the arguments just developed, I offer a stylized and general history of the LIO's development from 1919 to the present, roughly following Ikenberry's periodization. ${ }^{24}$

\section{LIO 1.0: Racial Hierarchy and Racial Nations}

To place the 1919 LIO in historical context, we need to begin earlier. Starting with the end of the eighteenth century, a blend of pseudo-scientific approaches, prejudices, and economic-political interests gradually cohered into a white supremacist ideology based on three main tenets: (1) humankind is divided into biological races, with distinct and relatively stable physical markers; (2) these stand for distinct social, psychological, moral, and political abilities; and (3) based on these, races can be ranked hierarchically, with whites at the top. ${ }^{25}$ White supremacy was intertwined with nationalism, as they emerged together and shaped each other, especially in the nineteenth century. The result was a particular type of racial nationalism-white nationalism-which conceived of nations in biological terms.

White nationalism and white supremacy legitimated the consolidation of already acquired colonies and the acquisition of new ones. ${ }^{26}$ Many, but not all, imperialists were white supremacists, proclaiming that "the 'darker, lesser breeds' and 'inferior races' must make way for advanced and superior white civilization." 27 Western states such as Britain, France, Belgium, Portugal, Italy, the Netherlands, and Germany subjugated much of the world. The United States annexed Hawaii and controlled Cuba, Puerto Rico, Guam, and the Philippines. Russia colonized parts of

23. For a domestic example see ibid., 18, 297 n54.

24. Ikenberry 2009. The main difference is that I characterize the current order as the LIO 2.5 rather than 3.0.

25. For various aspects of white supremacy see Lauren 1996, especially chapters 1 and 2; Crenshaw et al. 1995; Grovogui 1996; Mills 1997; Lake and Reynolds 2008.

26. Lauren 1996, 43-46; for normative analyses of race and empire see Bell 2019.

27. Lauren 1996, 44. 
Central Asia, the Caucasus, and the Far East. Similar racial ideologies undergirded settler colonialisms in South Africa, the Americas, Australia, New Zealand, and Siberia. Other countries employed their own racist ideologies, illustrated by Japan's colonialism in Asia and oppression of indigenous people such as the Ainu. Racially justified imperialism is an essential backdrop to racial coalitions' struggles over subsequent RDRs.

The rise of the pre-World War II traditional coalition is tied to unifying strands of white nationalism and supremacy, which stressed white solidarity against ostensibly threatening racial others. They eased Anglo-American rapprochement and the emergence of a transnational white community in the late nineteenth century. ${ }^{28}$ This community was the center of the traditional coalition, whose principal members included statesmen such as US President Woodrow Wilson and Australia's Prime Minister William Hughes; white supremacist and nationalist nongovernmental organizations such as the Asiatic Exclusion League in the United States and the White Race League in New Zealand; and advocates of scientific racism such as Karl Pearson, Gustave Le Bon, and Lothrop Stoddard.

Although the traditional coalition was dominant, it encountered some resistance. Notable examples include Ethiopia's victory over Italy at the Battle of Adowa (1896), the Boxer Rebellion (1899-1901), the First Pan-African Conference (1900), and Russia's defeat in the Russo-Japanese War (1904-5). Resistance increased after World War I, as the war weakened the traditional coalition and energized the transformative coalition, whose center of gravity was non-Western. This coalition included anticolonial nationalists such as Mohandas Karamchand Gandhi from India, statesmen such as Baron Makino Nobuaki from Japan, Western and non-Western communists such as Wilhelm Münzenberg from Germany and Soong Ching-ling (Madame Sun-Yat-sen) from China, opponents of scientific racism and white supremacy such as W.E.B. DuBois and Alain LeRoy Locke from the United States, and movements and organizations such as the Negritude movement and the National Association for the Advancement of Colored People (NAACP).

The two coalitions struggled over the first liberal order's RDR, established at the 1919 Paris Peace Conference. The dominant traditional coalition successfully imposed a regime based on white nationalism and white supremacy. The emblematic struggle between coalitions occurred over the inclusion of a racial equality clause in the League of Nations Covenant. The transformative coalition was led by the only nonwhite great power at the time, Japan, which hoped that such a clause would lower racial barriers to Japan's rise and the global mobility of its citizens. Japanese concerns regarding such barriers were valid, as a British Foreign Office document later explained:

We must realise too, that, although in polite talk with Japanese it is customary to say that the reasons for exclusion of Japanese are purely economic, yet as a matter of fact, there is a racial and a political antagonism to the Japanese in the countries 
concerned, which is stronger even than the economic antagonism ... Japan is the only non-white first-class Power. In every respect, except the racial one, Japan stands on a par with the great governing nations of the world. But, however powerful Japan may eventually become, the white races will never be able to admit her equality. If she can enforce her claim she will become our superior; if she cannot enforce it she remains our inferior; but equal she can never be. ${ }^{29}$

The core members of the traditional coalition included delegates from the British Empire (especially Australia and New Zealand) and the United States. Inspired by advocates of scientific racism and pressured by racist domestic organizations, they viewed Japan as a "Yellow Peril" that challenged white supremacy. ${ }^{30}$ Japan raised the issue of racial equality repeatedly, supported outside the League of Nations by groups like the Pan-Asian Society in China, Japanese residents in Hawaii, and the Second Pan-African Congress organized by DuBois in Paris in 1919.

The key session of the League of Nations Commission occurred on 11 April 1919. ${ }^{31}$ Japanese delegates made an impassioned case for racial equality, which won over the majority of the delegates, but not the main traditionalists. The British Empire was somewhat torn between its Japanese ally's and India's support for racial equality and white dominions' opposition to it, but it eventually embraced the latter position. The United States was also reluctant to support racial equality, not least because of California's strong anti-Japanese lobby. Woodrow Wilson, the commission's chair, asserted that adopting such an important clause required unanimity. This gave the traditional coalition the veto over racial equality, so Japan's proposal failed.

Other aspects of the LIO supported white supremacy too. The right to self-determination was largely limited to European nations. The League's mandate system reflected the racial hierarchy of the time, prolonged colonialism, and under-represented indigenous interests. ${ }^{32}$ The League did little against racial discrimination and related problems raised by Iroquois petitions, Universal Negro Improvement Association complaints, and Italy's invasion of Ethiopia (1935). ${ }^{33}$ Many states had racist citizenship and immigration laws, reflecting and reinforcing the white supremacist diversity regime. ${ }^{34}$

During the interwar period, this RDR was increasingly challenged by the transformative coalition. It included the Negritude movement, Pan-African Congresses, the Pan-African association Ligue Universelle pour la Défense de la Race Noire,

29. British Foreign Office (F. Ashton-Gwatkin), 10 October 1921, Memorandum respecting British neutrality in the events of a Japanese-American War, Document 12, (4221/223/23) Confidential Print and Piece No. 11942/161, 17, 33.

30. Búzás 2013.

31. Shimazu 1998, 30; United States Department of State, Papers Relating to the Foreign Relations of the United States (hereafter FRUS), The Paris Peace Conference, 1919, 289-91.

32. Anghie 2004, chapter 3.

33. Lauren 1996, chapter 4.

34. See Gerstle 2001; Lake and Reynolds 2008; MacMaster 2001. 
and the Pan-Asian Conference. Noteworthy too was the League Against Imperialism, supported by anticolonial nationalists and Western communists, even if it ultimately disappointed hopes that it would become "the non-white counterforce to the League of Nations." "35 Although the transformative coalition grew increasingly disillusioned with LIO 1.0 and its inegalitarian diversity regime, both persisted until World War II.

\section{LIO 2.0: Racial Equality and Nonracial Nations}

World War II undermined LIO 1.0 by discrediting its RDR and mobilizing its opponents. In its wake, there was much agreement that many atrocities committed during the war were rooted in racial nationalism and supremacy, exemplified most obviously by Nazi Germany and the Holocaust. As a United Nations Educational, Scientific, and Cultural Organization (UNESCO) document put it, "The great and terrible war which has now ended was a war made possible by the denial of democratic principles of the dignity, equality, and mutual respect for men, and by the propagation, in their place, through ignorance and prejudice, of the doctrine of the inequality of men and races." ${ }^{36}$ White supremacy suffered further damage from Japan's early victories in the war and anticolonial nationalists such as Subhas Chandra Bose of India, Ba Maw of Burma (Myanmar), and Achmed Sukarno of Indonesia. They and many others were determined to resist the first LIO's white supremacist RDR.

Already during World War II, Allied powers felt pressure to distinguish themselves from their Nazi opponents. However, they worried that embracing racial equality would undermine segregation at home and colonial empires abroad. With a few exceptions, they preferred generic references to sovereign equality and human rights. In 1944 at Dumbarton Oaks, Britain, the United States, and the Soviet Union were unreceptive to China's proposal that the United Nations' fundamental principles include racial equality. ${ }^{37}$

Yet in 1945, racial equality had much more support than it had in 1919, as would become evident in San Francisco. DuBois's criticisms of Dumbarton Oaks articulated transformative objections about "leaving untouched, save by vague implication, the causes of war, especially those causes which lurk in rivalry for power and prestige [and] race dominance." ${ }^{38}$ Delegates from Argentina, Brazil, Chile, China, Cuba, the Dominican Republic, France, Haiti, India, Iraq, Mexico, Panama, the Philippines, Ukraine, and Uruguay, among others, argued for racial equality. ${ }^{39}$ The

35. Lauren 1996, 125.

36. UNESCO, Conference for the Establishment of the United Nations Educational, Scientific, and Cultural Organization, ECO/CONF./29, 16 November 1945, 93, emphasis added.

37. Lauren 1996, 158-60.

38. Quoted in Ibid., 162.

39. Documents of the United Nations Conference on International Organization, San Francisco, 1945, Volume I: 115, 260, 311, 455, 704; Volume III: 40, 42, 49, 58, 275, 300, 608, 639; Volume VI: 564, 576,643 . 
Soviets also changed their position to embrace racial equality. Other transformative actors included some Arab League representatives, the NAACP and the National Council of Negro Women from the United States, the Council of Christians and Jews from Britain, and the Six Nations Iroquois Confederacy from Canada. Most African states were still colonized and had limited influence in San Francisco, but many black internationalists championed Africa's decolonization in venues such as the Fifth Pan-African Congress (1945). ${ }^{40}$

The traditional coalition, centered on "Anglo-Saxon" states and European colonial powers, worked to limit the scope of racial equality. A segregated United States, White Australia, apartheid South Africa, and others "had some skeleton in their cupboard the key to which they would much prefer to keep in their own hands." 41 They could not openly advocate white supremacy, and some genuinely embraced a limited notion of racial equality. They championed domestic jurisdiction partly to limit the scope of racial equality. US delegates such as John Foster Dulles were reassured that domestic jurisdiction guarded against international challenges to "the Negro problem in the South." 42 The British Foreign Office shared a similar position, indicated in the memorandum "World Organization: Racial Equality and Domestic Jurisdiction."43 Australia's Minister of External Affairs, Herbert Evatt, shifted from supporting United Nations interventionism to advocating domestic jurisdiction because he grew concerned that the organization might challenge the White Australia policy. ${ }^{44}$ Some smaller states could be seen as part of both coalitions because they supported racial equality but also favored domestic jurisdiction as a guarantee against great power meddling in their domestic affairs. ${ }^{45}$

The new order's RDR reflected a compromise between the two coalitions. The transformative coalition succeeded in building the new regime on racial equality. As a result of its efforts, Articles 1, 13, 55, 62, 68, 73, and 76 of the United Nations Charter contain the principle of racial equality. As a result of the traditional coalition's efforts, Article 2(7) limits the scope of this principle through the doctrine of domestic jurisdiction. It stipulates that, except for UNSC enforcement action under Chapter VII, "Nothing contained in the present Charter shall authorize the United Nations to intervene in matters which are essentially within the domestic jurisdiction of any state or shall require the members to submit such matters to settlement under the present Charter." The scope of "domestic jurisdiction" has been the subject of subsequent interpretive struggles, and its scope has varied over time. Nonetheless, domestic jurisdiction has facilitated the endurance of domestic racism under the

40. Getachew 2019, 72-73.

41. Gladwyn Jebb 1972, 160.

42. Original Minutes of the Fifty-First Meeting of the US Delegation, 23 May 1945, in US State Dept., FRUS 1945, 1:853-55. States' rights are the domestic equivalent of this strategy in the United States.

43. Public Record Office/Foreign Office 371/46324, 8 June 1945.

44. US State Dept., FRUS 1945 General, 871.

45. Documents of the United Nations Conference on International Organization, 1945, VI:521; Lauren $1996,166$. 
shield of sovereignty, illustrating the concept of "embedded racism." Numerous other aspects of the new LIO, including provisions regarding trusteeships and colonies, reflected similar intercoalitional compromises. ${ }^{46}$

As the Cold War heated up in the late 1940s, the scope of LIO 2.0 contracted from universal membership to one largely based on Western democracies. ${ }^{47}$ This narrower LIO reflected racial bargains similar to those of its broader precursor, but also included some important victories of the traditional coalition. In addition to domestic jurisdiction clauses, some Western states included colonial clauses in international agreements to limit the application of unwanted obligations, such as racial equality, to their colonies. Some institutions were built on vestiges of the first liberal order's RDR. In addition to shared economic and security interests, shared white identity among member states aided the creation of the North Atlantic Treaty Organization. ${ }^{48}$ The new RDR favored nonracial nationalism and racial equality, but through embedded racism it allowed the persistence of racism generally, and white nationalism and supremacy specifically, under the shield of sovereignty.

\section{LIO 2.5: The Limited Consolidation of the Egalitarian RDR}

Anticolonial nationalists and civil rights advocates played key roles in consolidating the post-World War II order's RDR through transformative struggles against colonialism and domestic racism in the West. They saw these as two sides of the same problem rooted in white nationalism and white supremacy, and cooperated against them. The traditional coalition limited the pace and scope of this consolidation, but could not stop its advance to what can be labeled LIO 2.5.

Anticolonial nationalists helped narrow the gap between substantive racial inequality and the RDR's formal racial equality through decolonization. Much of this historic development unfolded in the three decades following World War II. Decolonization enjoyed the support of black nationalist women and actors such as the NAACP, best known for their domestic antiracist struggles. ${ }^{49}$ Between 1955 and 1968, thirty-seven newly decolonized African states joined the United Nations, raising their number from three of sixty member states to forty-one of $126 .{ }^{50}$

The increase in Afro-Asian member states shifted the balance of power in the UNGA in favor of the transformative coalition, helping them place racial equality and decolonization at the top of the agenda. In addition to those mentioned earlier, notable members of this coalition included Tanzania's first president, Julius Nyerere, Ghana's first prime minister and president, Kwame Nkrumah, and

46. For an overlapping argument that the LIO is built not just by Western great powers but also by nonWestern actors, see Tourinho 2021.

47. Ikenberry 2009, 76-77.

48. Hemmer and Katzenstein 2002.

49. See Anderson 2014; Blain 2018.

50. Kay 1969, 20-21. 
politically active intellectuals such as Aimé Césaire, Léopold Sédar Senghor, and Frantz Fanon. The Afro-Asian contingent of the transformative coalition worked closely against racism and colonialism at the United Nations and beyond, including conferences at Bandung (1955), Accra (1958), and Belgrade (1961). The Soviets and some South Americans often voted with it. This increasing clout accelerated decolonization, adding more new members to the United Nations, which further strengthened the transformative coalition.

Anticolonial nationalists were not simply concerned with extending sovereignty to former colonies. As Getachew eloquently elucidates, they were also engaged in "worldmaking," pursuing an egalitarian international order. ${ }^{51}$ Many of their efforts advanced the egalitarian RDR. Some formally modified the United Nations Charter to make the United Nations Economic and Social Council (ECOSOC) and nonpermanent UNSC memberships more inclusive. Others aimed to reinterpret the charter through resolutions, such as the Declaration on the Granting of Independence to Colonial Countries and Peoples (UNGA Resolution 1514 of 1960), to increase states' obligations regarding racial equality and decolonization. ${ }^{52}$ Still others extended racial equality from the charter through a thick web of human rights instruments, starting with the first legally binding human rights treaty, the International Convention on the Elimination of All Forms of Racial Discrimination (ICERD). In 1982, the transformative coalition established the United Nations' first Working Group on Indigenous Populations.

The transformative coalition also repeatedly challenged embedded racism, the limitation that domestic jurisdiction placed on racial equality. Admittedly, during the Cold War, it achieved only limited success against apartheid South Africa. Traditionalists, including the United States, saw South Africa as a key provider of raw material and a strategic anti-Communist ally, and blunted transformative pressures. This is not to deny that the United States also had transformative inclinations, but these were trumped by domestic racism and by what the United States saw as Cold War imperatives.

In contrast, Cold War imperatives helped racial equality at home. The United States could not ignore foreign criticisms of domestic racism, given Cold War competition with the Soviets for Third World allies. ${ }^{53}$ Initial post-World War II domestic antiracist efforts included black soldiers' support for the Double V campaign that pursued victory over the Axis abroad and racism at home, and DuBois's UN petition, "An Appeal to the World" (1947), which documented racial discrimination in the United States. Gradually such efforts gained momentum. Leaders of decolonized states supported the US civil rights movement against discrimination that some personally experienced during United Nations visits. They criticized the United Nations for failing to act on DuBois's petition, visited African American communities as 
Nkrumah did in Harlem, and passed supportive resolutions at the United Nations and other venues such as the Organization of African Unity. ${ }^{54}$ Secretary of State Dean Rusk stated that the "biggest single burden that we carry on our backs in our foreign relations in the 1960s is the problem of racial discrimination here at home." ${ }^{55}$ Subject to domestic and international pressures, the United States replaced domestic racist laws with racial equality laws. Other Western states also replaced explicitly discriminatory domestic legislation, including immigration and citizenship laws. ${ }^{56}$

These achievements considerably strengthened LIO 2.5's RDR, but they were limited in several ways. The monitoring and enforcement mechanisms of most international racial equality and human rights instruments remained insufficient. Some states, including the United States, were reluctant to ratify them, weakened them through reservations and similar means, or adopted amendments to make them non-self-executing. Many achievements did not extend self-determination to indigenous groups subject to settler colonialism, and they often overlooked racism in non-Western states. Global antiracist struggles were complicated by the 1975 UNGA resolution that equated Zionism with racism, which undercut Western support for antiracism resolutions passed the same day and for subsequent world conferences against racism. ${ }^{57}$

Most relevant for our discussion, the RDR 2.5 was premised on a narrow idea of racial equality, understood primarily as equal treatment. This conception is more useful for countering the direct racism of unequal treatment stemming from individual prejudices than for addressing indirect, systemic, racism understood as the differential impact of apparently race-neutral institutions and policies on different racial groups. In part because of this narrow conception, de facto racial inequality continued. Despite some material progress, the gap between the Global South and the North remained wide. This material inequality cannot be reduced to race, but it has been racial in two main senses: most of the wealthy have been white and most of the poor have not; and a considerable part of this inequality is the cumulative effect of centuries of slavery and imperialism justified by white supremacy. The transformative coalition's attempts to alleviate inequality through a New International Economic Order in the 1970s were rebuffed by the traditional coalition, whose core Western members controlled international economic institutions. ${ }^{58}$

\section{Challenges to the RDR and the Future of the Liberal Order}

Currently, both coalitions are dissatisfied with RDR 2.5, subjecting it to sustained contestation. This section discusses the nature of this contestation, ponders emerging

56. See Lake and Reynolds 2008, 353; Lauren 1996, 251-52; MacMaster 2001, part 3. Nonetheless, key restrictions on immigrants' rights remained. Goodman and Pepinsky 2021.

57. Lauren 1996, 257-59.

58. See Getachew 2019; Murphy 1984. 
powers' racial nationalisms and inequality, and sketches possible futures for this regime and the LIO.

The transformative coalition scored important victories after the Cold War, including the fall of apartheid South Africa, the last bastion of formal white supremacy. Yet profound disappointment remains with the egalitarian RDR's limited impact on substantive inequality, which this coalition considers ineffective at best and complicit in producing inequality at worst. Post-apartheid South Africa embodies some of these dissatisfactions because it is the world's most unequal country despite achieving formal racial equality more than twenty-five years ago. ${ }^{59}$ In Western countries such as the United States, racial inequality persists in education, employment, income, health, housing, political representation, and criminal justice. ${ }^{60}$ At the international level, transformative actors decry jarring inequalities between rich Western and poor African states, and lament biases against the latter in international institutions. Admittedly, some emerging powers such as China have benefited handsomely from their participation in the LIO's trade regime, narrowing material inequality between themselves and Western states. Here, transformative grievances underline inequality within emerging powers and these powers' under-representation in LIO institutions.

Dissatisfied with the narrow racial equality of RDR 2.5 , the transformative coalition continues to pursue its revision. A central aim is to expand the notion of racial equality from equal treatment to equal opportunity and even equal outcomes, in order to counter systemic racism more effectively. The coalition has achieved some legal victories, however limited, including the European Union's Race Equality Directive and recent European Court of Human Rights jurisprudence. ${ }^{61}$ Transformative efforts have broadened the scope of international racial equality laws to include the Roma, indigenous people, castes, and intersectional forms of discrimination. Domestically, transformative actors promote broader notions of antiracism. ${ }^{62}$ They advocate affirmative action, multiculturalism, and welcoming immigration and refugee policies. The diversification of curricula, reparations, and the removal of white supremacist symbols are also on the agenda.

The traditional coalition has responded with a backlash against transformative efforts, going as far as to champion withdrawal from key LIO institutions. This coalition has long embraced, at least rhetorically, the colorblind and narrow racial equality of LIO 2.5, which obscures systemic racism and legitimates racial inequality by linking it to merit. ${ }^{63} \mathrm{~A}$ more recent development, perhaps more damaging to the $\mathrm{RDR}$, is the traditionalist shift toward "white protectionism." 64 It repurposes the

59. Katy Scott, "South Africa Is the World's Most Unequal Country," CNN, 10 May 2019.

60. Harris and Lieberman 2013; "The Grim Racial Inequalities Behind America's Protests," The Economist, 3 June 2020.

61. For a critical discussion see Búzás 2020.

62. In the United States see Kendi 2019.

63. Inayatullah and Blaney 2018.

64. Smith and King 2020. 
language of antidiscrimination and multiculturalism to depict whites as victims of discrimination and to demand their protection. It is not entirely new, as long-standing complaints about affirmative action as "reverse racism" show, but it is growing stronger. Much of this protectionism is animated by "ethnocultural anxiety," from the West to Russia and Eastern Europe, that today's white majorities will be tomorrow's minorities, given trends in immigration and fertility rates. ${ }^{65} \mathrm{It}$ is augmented by economic troubles and China's rise, perceived as a "status threat" to international Western dominance. ${ }^{66} \mathrm{In}$ response, the traditional coalition has employed measures from restrictive immigration and the weakening of racial equality laws to minority voter suppression and transnational white supremacist movements. Some in the radical right envision an international order based on "ethno-homogenous polities." 67

Colliding pressures from the two coalitions resemble a catch-22 situation for the RDR. For the traditional coalition, the regime goes too far, threatening white dominance. For the transformative coalition, the regime does not go far enough, enabling persistent racial nationalism and inequality. The two sides are not equally correct. As the adage puts it, "When you're accustomed to privilege, equality feels like oppression." Other racially tainted issues, such as the Israeli-Palestinian conflict, augment grievances against the RDR as illustrated by the 2001 World Conference Against Racism in Durban. ${ }^{68}$

\section{Emerging Powers, RDRs, and the Future of the Liberal Order}

Before discussing possible futures for the RDR and the liberal order, we must broaden the discussion from white nationalism and white supremacy to other strands of racial nationalism and hierarchy. During much of the LIO's history, the battleground issue was Western racism, but as material power shifts away from the West, the racism and antiracism of emerging powers become more consequential for struggles over the RDR. A glance at India and China suggests that their transformative stance, exhibited in response to Western racism, cannot be taken for granted.

India's postcolonial identity and commitment to nonalignment have historically made it ambivalent about the LIO, but experts deem its current aspirations compatible with the order. ${ }^{69}$ Yet the Hindu nationalism of Prime Minister Narendra Modi and the Bharatiya Janata Party sits less comfortably with the current RDR. Hindu nationalism defines the nation not only in religious but also in ethnoracial terms. In a departure from the "composite nationalism" of India's constitution, which recognizes all communities as equal members of the nation, Hindu nationalism asserts Hindu primacy

65. See Kaufmann 2019; Laruelle 2017, 97-98.

66. Mutz 2018.

67. Drolet and Williams 2018.

68. Report of the World Conference Against Racism, Racial Discrimination, Xenophobia and Related Intolerance, A/Conf.189/12.

69. Chatterjee Miller 2018. 
and relegates others to second-class citizens. ${ }^{70}$ India has affirmative policies for disadvantaged minorities, but it has vigorously opposed the extension of international racial equality laws to counter caste discrimination. Some strands of Hindu nationalism depict international politics as a struggle between civilizations, and posit Hindu superiority. ${ }^{71}$

The illiberalism of the Chinese Communist Party translates into hostility to liberal aspects of the order, such as human rights. The racial aspects of China's vision are especially troubling for the RDR. The Chinese constitution refers to a "multinational state," but racial nationalism privileging the Han "race-nation" at the expense of minorities has a long pedigree. ${ }^{72}$ More than one million Uighurs are interned in "re-education camps," which critics called "apartheid with Chinese characteristics."73 African immigrants often suffer discrimination, as illustrated by events in Guangzhou that drew unusual criticisms from African officials in April 2020.74

What are the plausible futures for the liberal order's contested RDR? The LIO has been historically resilient. ${ }^{75}$ The RDR is no exception, but it is likely to endure in a modified form. If the traditional coalition obtains dominance, the RDR could regress to the 2.0 version. White nationalists could cooperate with racial nationalists in India, China, and elsewhere to weaken racial equality, strengthen racial nationalism, and protect the dominance of racial and ethnic majorities under the shield of sovereignty. This would amount to re-embedding the racism of LIO 2.0, but this time with more non-Western support. By contrast, if the transformative coalition gains dominance, the regime could advance to 3.0 or beyond, favoring nonracial nationalism and a broad notion of equality. But significant racial progress tends to come in the wake of calamitous events such as major wars. It remains to be seen if the current situation is sufficient to advance progress. It is possible that transformative forces will capitalize on global protests supporting Black Lives Matter and the racial inequalities revealed and reinforced by the pandemic to energize new civil rights movements and gain political power in the United States and elsewhere.

If neither coalition achieves dominance, some compromise that satisfies cross-coalitional majorities could produce a less radical modification in LIO 2.5 and its RDR. One domestic compromise could involve restricted immigration in return for sustained measures advancing racial equality. In a domestic-international compromise, the traditional coalition might accept advances in racial equality internationally (such as more representation for emerging powers in international organizations than in past orders) in exchange for protecting the current dominance of racial and ethnic majorities. Finally, a less likely scenario is that if relatively evenly matched coalitions do not compromise, the RDR and perhaps the broader LIO could break down. Regions would rely on their

70. Varshney 2019, 69, 75.

71. Chatterjee Miller 2018, 81-82.

72. Dikötter 1992.

73. "Apartheid with Chinese Characteristics," The Economist, 31 May 2018.

74. David Pilling and Sue-Lin Wong, "China-Africa Relations Rocked by Alleged Racism over Covid-

19," Financial Times, 13 April 2020.

75. Lake, Martin, and Risse forthcoming. 
own RDRs, many of which already exist and vary considerably regarding their hospitability to racial equality and nonracial nationalism. In sum, the stakes of the transformative-traditionalist struggles are high because they will determine whether we will inhabit a more racist or a more antiracist world. Transformative forces must mobilize to defend and advance an antiracist RDR and liberal international order.

\section{Conclusion}

This article provides a broad framework to illuminate the role of race in the order's origins and development, and to help us make sense of the order's current racial challenges. This is an important contribution to mainstream IR, which often overlooks race. For example, conventional approaches might discuss the inclusion of domestic jurisdiction in the United Nations Charter, but rarely note the racist motivations behind it. I highlight that domestic jurisdiction was designed in part to reduce the scope of the order's egalitarian diversity regime and to protect domestic racism from international interference. This is what I call the LIO's "embedded racism," a conceptual contribution of this article. For IR scholars already attentive to race, this article offers a synthetic framework. It brings together a diverse set of issues related to racism and antiracism that are often studied separately, and demonstrates that they have jointly shaped the LIO.

The argument illustrates aspects of all four of the framework article's analytic lessons, but especially the first and fourth: (1) international orders are clubs that include as well as exclude, and (4) domestic politics matter for the LIO. ${ }^{76}$ The LIO has racially exclusionary aspects, although these vary across RDRs. The pre-World War II LIO, built on white nationalism and white supremacy, excluded actors seen as non-white or included them in an unequal fashion. But even the post-World War II LIO, favoring racial equality and nonracial nations, has had exclusionary and discriminatory dimensions. This article recognizes advances in the RDR and Afro-Asian contributions to it, corroborating Tourinho's argument in this issue. However, although decolonization offered new states the trappings of formal equality (sovereignty) and racial equality laws did the same for minorities in Western states, substantive equality remains elusive both internationally and domestically. The findings also support the framework article's fourth lesson, stressing that domestic politics are intertwined with the LIO in numerous ways. This was evident in the joint efforts of anticolonial nationalists and civil rights advocates to consolidate the egalitarian RDR 2.5. Struggles over embedded racism evince that domestic racial concerns shape the designs of RDRs, which then impact domestic institutions and policies.

I conclude by joining other scholars doing important work on race in advocating more attention to this topic. ${ }^{77}$ Inspired by their work, I propose a racial agenda for

76. Lake, Martin, and Risse forthcoming.

77. See Anievas, Manchanda, and Shilliam 2015; Grovogui 1996; Henderson 2017; Klotz 2017; Rosenberg 2019; Sajed and Persaud 2018; Vucetic 2011. 
mainstream IR. To begin, we need more disciplinary self-reflection. The previous historical discussion shows that intellectuals have played significant roles in racial coalitions. Which racial coalition are we part of, individually and collectively? Studies shed light on mainstream IR's Eurocentrism and its silence on race and related issues. ${ }^{78}$ From this perspective, we are part of the traditional coalition that at best ignores racial inequality and at worst contributes to it. There is much we can do to be firmly in the transformative coalition. We should advance racial equality through all facets of our work, including teaching, mentoring, hiring, service, and research. The remainder of the agenda focuses on research.

First, scholars should extend the study of race from explicitly racial aspects of the LIO, such as racial equality provisions, to apparently race-neutral issues, such as domestic jurisdiction. Methodologically diverse studies have revealed racial aspects of apparently nonracial issues, including foreign aid, humanitarian intervention, alliances, and international law. ${ }^{79}$ They provide a wide array of supportive evidence, such as racial discourse and unjustifiable disproportionate impact on certain racial groups. Mainstream IR could build on this work to offer nuanced and wellresearched studies about the impact of race on such apparently race-neutral aspects of the LIO.

Second, scholars could extend this study from white nationalism and white supremacy to other forms of racial nationalism and hierarchy. We should learn more about racism and antiracism in emerging powers such as India and China to better understand their impact on the RDR. Scholars could further develop the concept of "embedded racism" and examine how it has protected domestic racism beyond the West. Work on race in emerging powers could also be profitably combined with IR research on status to yield improved theories of when China might experience a racial glass ceiling or "status immobility" and turn to systemic revisionism. ${ }^{80}$

Third, future work should go beyond this article's intimation that RDRs can legitimate LIOs and should provide sustained analyses of the relationship between RDRs and LIO legitimacy. Research on race and representation in other subfields of political science provides inspiration. Some studies suggest that racial inclusiveness can increase the legitimacy of domestic institutions through descriptive representation and improved problem solving. ${ }^{81}$ But they also caution that descriptive representation might come at the expense of substantive representation, and that it might increase institutional legitimacy in the eyes of one group while reducing it for others. ${ }^{82}$ Building on these studies, IR scholars could analyze when and to what extent racial inclusiveness improves the LIO's legitimacy. This would be an important contribution to current debates about representation in international organizations.

78. See Crawford 2017; Henderson 2017; Hobson 2012; Vitalis 2015.

79. See Baker 2015; Grovogui 1996; Parmar 2018; Sabaratnam 2017; Vucetic 2011.

80. Ward 2017.

81. See Mansbridge 1999; Page 2007.

82. See Mansbridge 1999, 638; Scherer and Curry 2010. 
The pursuit of this research agenda must avoid essentializing race. There is an unfortunate tendency to pay lip service to racial categories being malleable, internally heterogenous, and overlapping social constructs but to treat them in empirical analyses as fixed, internally homogenous, and mutually exclusive. ${ }^{83}$ Aligning our methods and empirical analyses with our professed ontology of racial constructivism is vital to ensuring empirical accuracy and avoiding the legitimation of injustices produced through essentialized notions of race. The dangers of essentialization are lower in interpretive, ethnographic, and historical studies that examine how race is constructed, changes, and works in specific settings in ways that intersect with class, gender, and nation. In this vein, scholars could also consider how RDRs impact ethnic and racial identities. Barnett provides an exemplary study of how variation in diversity regimes shaped Jewish identities. ${ }^{84}$ Incorporating novel issues related to genomics, multiracialism, and artificial intelligence biases in a critical fashion could offer a fresh angle to such research.

The risks of essentialization are higher in variable-focused research. To reduce these risks, studies could employ variables related to but other than race, such as those measuring racial prejudice and discrimination. Scholars who treat race as a variable could capture its malleability and fluidity if they assess it on "more than one dimension (e.g., racial self-classification, ancestry, reflected race, phenotype), employ different measurement approaches (experiment, close-ended survey, forced-choice survey, open-ended survey), and consider asking questions at different time periods and in different contexts." 85 They should also allow variation in racial categories across space, time, and contexts, and allow actors to fall into multiple racial categories simultaneously. Finally, researchers should recognize that race is built on a "complex fusion" of factors, from physical traits to diet, language, and clothing. ${ }^{86}$ Disaggregating race into more specific dimensions can counter essentialization by drawing attention to the social nature of many of these dimensions and to the vast variation on these dimensions among individuals lumped together in the same broad racial category.

\section{References}

Adler-Nissen, Rebecca, and Ayse Zarakol. 2020. Struggles for Recognition: The Liberal International Order and the Merger of its Discontents. International Organization 75 (2):https://doi.org/10.1017/ S0020818320000454.

Aktürk, Şener. 2011. Regimes of Ethnicity: Comparative Analysis of Germany, the Soviet Union/PostSoviet Russia, and Turkey. World Politics 63 (1):115-64.

Anderson, Carol. 2014. Bourgeois Radicals: The NAACP and the Struggle for Colonial Liberation, 19411960. Cambridge University Press.

83. For this criticism see Davenport 2020, 235; Sen and Wasow 2016, 502.

84. Barnett 2020.

85. Davenport 2020, 234.

86. Sen and Wasow 2016, 506. 
Anghie, Antony. 2004. Imperialism, Sovereignty and the Making of International Law. Cambridge University Press.

Anievas, Alexander, Nivi Manchanda, and Robbie Shilliam, eds. 2015. Race and Racism in International Relations. Routledge.

Baker, Andy. 2015. Race, Paternalism, and Foreign Aid: Evidence from US Public Opinion. American Political Science Review 109 (1):93-109.

Barnett, Michael. 2020. The Jewish Problem in International Society. In Culture and Order in World Politics, edited by Andrew Phillips and Christian Reus-Smit, 232-49. Cambridge University Press.

Bell, Duncan, ed. 2019. Empire, Race and Global Justice. Cambridge University Press.

Blain, Keisha. 2018. Set the World on Fire: Black Nationalist Women and Global Struggle for Freedom. University of Pennsylvania Press.

Búzás, Zoltán I. 2013. The Color of Threat: Race, Threat Perception, and the Demise of the Anglo-Japanese Alliance (1902-1923). Security Studies 22 (4):573-606.

Búzás, Zoltán I. 2018. Is the Good News About Law Compliance Good News About Norm Compliance? The Case of Racial Equality. International Organization 72 (2):351-85.

Búzás, Zoltán I. 2020. Evading International Norms: Race and Rights in the Shadow of Legality. University of Pennsylvania Press.

Chatterjee Miller, Manjari. 2018. China, India and Their Differing Conceptions of International Order. In The China-India Rivalry in the Globalization Era, edited by T.V. Paul, 75-93. Georgetown University Press.

Crawford, Neta. 2017. Native Americans and the Making of International Society. In The Globalization of International Society, edited by Tim Dunne and Christian Reus-Smit, 102-21. Oxford University Press.

Crenshaw, Kimberlé, Neil Gotanda, Gary Peller, and Kendall Thomas, eds. 1995. Critical Race Theory. The New Press.

Davenport, Lauren. 2020. The Fluidity of Racial Classifications. Annual Review of Political Science 23: 221-40.

DeFalco, Randle, and Frédéric Mégret. 2019. The Invisibility of Race at the ICC. London Review of International Law 7 (1):55-87.

Dikötter, Frank. 1992. The Discourse of Race in Modern China. Stanford University Press.

Doty, Roxanne Lynn. 1999. Racism, Desire, and the Politics of Immigration. Millennium 28 (3):585-606.

Drolet, Jean-Francois, and Michael Williams. 2018. Radical Conservatism and Global Order: International Theory and the New Right. International Theory 10 (3):285-313.

Dudziak, Mary. 2000. Cold War Civil Rights. Princeton University Press.

Gerstle, Gary. 2001. American Crucible: Race and Nation in the Twentieth Century. Princeton University Press.

Getachew, Adom. 2019. Worldmaking after Empire: The Rise and Fall of Self-Determination. Princeton University Press.

Gladwyn Jebb, Hubert Miles. 1972. The Memoirs of Lord Gladden. Weybright and Talley Inc.

Goodman, Sara Wallace, and Thomas Pepinsky. Forthcoming. The Exclusionary Foundations of Embedded Liberalism. International Organization 75 (2):<https://doi.org/10.1017/S0020818320000478>.

Grovogui, Siba. 1996. Sovereigns, Quasi Sovereigns, and Africans: Race and Self-Determination in International Law. University of Minnesota Press.

Gruffydd Jones, Branwen. 2008. Race in the Ontology of International Order. Political Studies 56:907-27.

Hanchard, Michael. 2018. The Spectre of Race: How Discrimination Haunts Western Democracy. Princeton University Press.

Harris, Fredrick, and Robert Lieberman, eds. 2013. Beyond Discrimination: Racial Inequality in a PostRacist Era. Russell Sage Foundation.

Hemmer, Christopher, and Peter Katzenstein. 2002. Why Is There No NATO in Asia? International Organization 56 (3):575-607.

Henderson, Errol. 2017. The Revolution Will Not Be Theorised: Du Bois, Locke, and the Howard School's Challenge to White Supremacist IR Theory. Millennium 45 (3):492-510.

Hobson, John. 2012. The Eurocentric Conception of World Politics. Cambridge University Press. 
Huntington, Samuel. 1996. The Clash of Civilizations and the Remaking of World Order. Simon and Schuster.

Ikenberry, John. 2009. Liberal Internationalism 3.0: America and the Dilemmas of Liberal World Order. Perspectives on Politics 7 (1):71-87.

Inayatullah, Naeem, and David Blaney. 2018. Race and Global Inequality. In Race, Gender, and Culture in International Relations, edited by Randolph B. Persaud and Alina Sajed, 116-34. Routledge.

Kaufmann, Eric. 2019. Whiteshift: Populism, Immigration, and the Future of White Majorities. Harry Abrams.

Kay, David. 1969. The Impact of African States on the United Nations. International Organization 23 (1): $20-47$.

Kendi, Ibram. 2019. How to Be an Antiracist. One World.

King, Desmond, and Rogers Smith. 2011. Still a House Divided: Race and Politics in Obama's America. Princeton University Press.

Klotz, Audie. 2017. Racial Inequality. In The Globalization of International Society, edited by Tim Dunne and Christian Reus-Smit, 362-79. Oxford University Press.

Lake, David, Lisa Martin, and Thomas Risse. Forthcoming. Challenges to the Liberal Order: Reflections on International Organization. International Organization 75 (2):<https://doi.org/10.1017/S0020818320000636>.

Lake, Marylin, and Henry Reynolds. 2008. Drawing the Global Color Line. Cambridge University Press. Laruelle, Marlene. 2017. Is Nationalism a Force for Change in Russia? Daedalus 146 (2):89-100.

Lauren, Paul Gordon. 1996. Power and Prejudice. Westview Press.

MacMaster, Neil. 2001. Racism in Europe 1870-2000. Palgrave.

Mansbridge, Jane. 1999. Should Blacks Represent Blacks and Women Represent Women? A Contingent "Yes." The Journal of Politics 61 (3):628-57.

Mills, Charles. 1997. The Racial Contract. Cornell University Press.

Murphy, Craig. 1984. The Emergence of the NIEO Ideology. Routledge.

Mutz, Diana. 2018. Status Threat, Not Economic Hardship, Explains the 2016 Presidential Vote. Proceedings of the National Academy of Sciences 115 (19):E4330-39.

Page, Scott. 2007. The Difference: How the Power of Diversity Creates Better Groups, Firms, Schools, and Societies - New Edition. Princeton University Press.

Parmar, Inderjeet. 2018. The US-Led Liberal Order: Imperialism by Another Name? International Affairs 94 (1):151-72.

Reus-Smit, Christian. 2017. Cultural Diversity and International Order. International Organization 71 (4): 851-85.

Rosenberg, Andrew. 2019. Measuring Racial Bias in International Migration Flows. International Studies Quarterly 63 (4):837-45.

Ruggie, John. 1992. International Regimes, Transactions, and Change: Embedded Liberalism in the Postwar Economic Order. International Organization 36 (2):379-415.

Sabaratnam, Meera. 2017. Decolonizing Intervention: International Statebuilding in Mozambique. Rowman and Littlefield.

Sajed, Alina, and Randolph Persaud. 2018. Race, Gender, and Culture in International Relations. Routledge.

Scherer, Nancy, and Brett Curry. 2010. Does Descriptive Race Representation Enhance Institutional Legitimacy? The Case of the US Courts. Journal of Politics 72 (1):90-104.

Sen, Maya, and Omar Wasow. 2016. Race As a Bundle of Sticks. Annual Review of Political Science 19: 499-522.

Shimazu, Naoko. 1998. Japan, Race, and Equality. Routledge.

Smith, Rogers, and Desmond King. 2020. White Protectionism in America. Perspectives on Politics. DOI: $<$ https://doi.org/10.1017/S1537592720001152>.

Tourinho, Marcos. Forthcoming. The Co-Constitution of Order. International Organization 75 (2):<https:// doi.org/10.1017/S0020818320000466>.

United Nations. 1945. Documents of the UN Conference on International Organization. United Nations Information Organizations. 
United Nations. 20 November 2018. Member States Call for Removing Veto Power, Expanding Security Council to Include New Permanent Seats, as General Assembly Debates Reform Plans for 15-Member Organ. Available at <https://www.un.org/press/en/2018/ga12091.doc.htm>. Accessed 2 October 2020.

United States, Department of State. Various years. Papers Relating to the Foreign Relations of the United States. United States Government Printing Office.

Varshney, Ashutosh. 2019. Modi Consolidates Power: Electoral Vibrancy, Mounting Liberal Deficits. Journal of Democracy 30 (4): 63-77.

Vitalis, Robert. 2015. White World Order, Black Power Politics. Cornell University Press.

Vucetic, Srdjan 2011. The Anglosphere: A Genealogy of a Racialized Identity in International Relations. Stanford University Press.

Ward, Steven. 2017. Status and the Challenge of Rising Powers. Cambridge University Press.

\section{Author}

Zoltán I. Búzás is Assistant Professor at Drexel University in Philadelphia, PA. He can be reached at zib23@drexel.edu.

\section{Acknowledgments}

I thank Emanuel Adler, Michael Barnett, Duncan Bell, Sarah Bush, Amelia Hoover Green, Hein Goemans, Naeem Inayatullah, Casey Mahoney, Boram Lee, Mark Pollack, Lauren Prather, Andrew Rosenberg, Robbie Shilliam, Rogers Smith, Robert Vitalis, Erik Voeten, Srdjan Vucetic, Alden Young, participants at the University of Pennsylvania's Browne Center Summer Virtual IR Workshop, participants at the IO@75 workshops, the editors of this special issue (David Lake, Lisa Martin, and Thomas Risse), and the reviewers and editors of International Organization for excellent comments. Erin Graham deserves special thanks.

\section{Key Words}

Liberal international order; racism; antiracism; racial equality; inequality; nationalism; racial coalitions; racial diversity regimes

Date received: October 10, 2019; Date accepted: July 17, 2020 